PEPATUDZU: Media Pendidikan dan Sosial Kemasyarakatan p-ISSN: 2087-3476 | e-ISSN: 2541-5700

\title{
PENGARUH MODEL PEMBELAJARAN INKUIRI TERHADAP HASIL BELAJAR MATEMATIKA PADA PESERTA DIDIK KELAS VIII SMP NEGERI 1 SUMARORONG
}

\author{
Nurhidayah $^{1}$, Irfawandi Samad ${ }^{2}$, Resky Hartono ${ }^{3}$ \\ ${ }^{1}$ Prodi Pendidikan Matematika Universitas Sulawesi Barat \\ 2,3Prodi Pendidikan Matematika Universitas Al Asyariah Mandar \\ e-mail: nurhidayah.inung19@gmail.com
}

\begin{abstract}
This research is experimental research. The population in this study was all students of Class VIII SMP Negeri 1 Sumarorong. Samples of 42 people consisting of class VIII A of 24 people and class VIII B as many as 18 people taken in random sampling. In this study used test instrument study results, learning model implementation sheet, and student activity sheet. The Data obtained is analyzed using descriptive statistical analysis and inferential statistical analysis. Based on data analysis results, both groups are normal and homogeneous distributions, so that hypothesis testing is performed using Test-t statistics. Based on the test-T statistics obtained: 1) The median value of the experimental class pretests 54.94 while the control class is 53.80, and the average Postest experimental class is 78.17, while the control class is 68. 2) for the implementation of the Inkuiri model's execution sheet after analyzed was obtained an average of $94 \%$, as well as the activity sheet of students for the experimental class obtained $61 \%$ while the control class was 38\%. and test-T acquired significant $0.024<0.05$ This indicates that $\mathrm{H} 0$ was rejected and $\mathrm{H} 1$ received. Thus, it can be concluded that the Learning model inquiry affect the outcome of mathematics for students of class VIII SMP Negeri 1 sumarorong.
\end{abstract}

Keywords: inquiry, outcome mathematics

\section{PENDAHULUAN}

Berdasarkan observasi dengan guru matematika SMP Negeri 1 Sumarorong menunjukkan bahwa rata-rata hasil belajar peserta didik kelas VIII pada ujian semester tidak mencapai Kriteria Ketuntasan Minimal (KKM) yang ditetapkan oleh sekolah adalah (60) Hal ini menunjukkan bahwa apa yang kita harapkan tidak sesuai dengan kenyataan. Sehingga perluh dicari solusi untuk meningkatkan hasil belajar matematika di sekolah tersebut. Hal ini disebabkan oleh beberapa faktor diantaranya kurang terciptanya suasana belajar yang 
menyenangkan bagi peserta didik, kemampuan-kemampuan dan kecerdasan tertentu, kesiapan guru, kesiapan siswa, kurikulum dan metode penyajiannya.

Model pembelajaran inkuiri merupakan model pembelajaran yang menjadikan peserta didik sebagai subjek belajar. Peserta didik melakukan berbagai aktivitas untuk menemukan suatu konsep yang baru.

Berdasarkan uraian di atas, diperlukan suatu pembelajaran yang dapat mengoptimalkan kerja otak siswa, sehingga penulis tertarik mengangkat judul "Pengaruh model pembelajaran inkuiri terhadap hasil belajar matematika pada peserta didik kelas VIII SMP Negeri 1 Sumarorong.

Menurut Nugroho (Nur dkk, 2016) salah satu model pembelajaran yang mengedepankan siswa aktif yaitu model pembelajaran inkuiri. Menurut Trianto (Purwanto, 2012) model pembelajaran pemrosesan informasi menekankan pada bagaimana seseorang berpikir dan dampaknya terhadap cara mengolah informasi tersebut, dan salah satu pembelajaran yang menekankan pada pemrosesan informasi yaitu model pembelajaran inkuiri.

Menurut Kunandar (Rini, 2016) pembelajaran inkuiri merupakan pembelajaran dimana siswa didorong untuk belajar melalui keterlibatan aktif mereka sendiri dengan konsep-konsep dan prinsip-prinsip. Guru mendorong untuk memiliki pengalaman dan melakukan percobaan yang memungkinkan siswa untuk menemukan prinsip-prinsip untuk diri mereka sendiri.

Adapun sintaks model pembelajaran inkuiri disajikan pada tabel 1 berikut: Tabel 1. Sintaks model pembelajaran inkuiri

(Sumber: Sanjaya, 2010)

\begin{tabular}{|c|l|}
\hline Fase & \multicolumn{1}{|c|}{ Peran Guru } \\
\hline $\begin{array}{c}\text { Fase I } \\
\text { Orientasi }\end{array}$ & $\begin{array}{l}\text { Guru merangsang dan mengajak peserta didik untuk } \\
\text { berfikir memecahkan masalah. Guru menjelaskan } \\
\text { topik, tujuan dan hasil belajar yang diharapkan, serta } \\
\text { pokok - pokok kegiatan yang harus dilakukan peserta } \\
\text { didik. }\end{array}$ \\
\hline $\begin{array}{c}\text { Fase II } \\
\text { Merumuskan masalah memberi kesempatan peserta didik untuk } \\
\text { mengidentifikasi berbagai permasalahan sebanyak } \\
\text { mungkin, memilihnya yang dipandang paling } \\
\text { menarik dan fleksibel untuk dipecahkan (hipotesis). }\end{array}$ \\
\hline Fase III & $\begin{array}{l}\text { Guru mengajukan berbagai pertanyaan untuk } \\
\text { mendorong peserta didik merumuskan jawaban } \\
\text { sementaranya. }\end{array}$ \\
\hline
\end{tabular}


PEPATUDZU: Media Pendidikan dan Sosial Kemasyarakatan p-ISSN: 2087-3476 | e-ISSN: 2541-5700

\begin{tabular}{|c|l|}
\hline $\begin{array}{c}\text { Fase IV } \\
\text { Mengumpulkan data }\end{array}$ & $\begin{array}{l}\text { Guru memberi kesempatan peserta didik untuk } \\
\text { mengumpulkan berbagai informasi yang relevan } \\
\text { dengan jelas, membaca literatur, mengamati objek, } \\
\text { mewawancarai sumber, dan mencoba (uji coba) untuk } \\
\text { membuktikan benar tidaknya hipotesis. }\end{array}$ \\
\hline $\begin{array}{c}\text { Fase V } \\
\text { Menguji hipotesis }\end{array}$ & $\begin{array}{l}\text { Guru membimbing proses penentuan jawaban yang } \\
\text { dianggap diterima sesuai dengan data atau informasi } \\
\text { yang diperoleh berdasarkan pengumpulan data. }\end{array}$ \\
\hline $\begin{array}{c}\text { Fase VI } \\
\text { Menarik kesimpulan }\end{array}$ & $\begin{array}{l}\text { Guru membimbing proses pendeskripsian temuan } \\
\text { yang diperoleh berdasarkan hasil pengujian hipotesis. }\end{array}$ \\
\hline
\end{tabular}

Selain itu, menurut Suardana (Karenta dkk, 2013) inkuiri terbimbing berorientasi pada aktivitas kelas yang berpusat pada siswa dan memungkinkan siswa belajar memanfaatkan berbagai sumber belajar sehingga siswa bukan hanya membaca kemudian mengahapal materi, namun juga diberikan kesempatan untuk berlatih berpikir dan bersikap ilmiah sehingga terjadi proses konstruksi pengetahuan sehingga dapat meningkatkan pemahaman siswa.

\section{METODE PENELITIAN}

Penelitian ini merupakan penelitian eksperimen semu (quasi experimental). Maksud penelitian ini untuk mengetahui ada atau tidak ada pengaruh dari model pembelajaran inkuiri terhadap hasil belajara matematika pada peserta didik kelas VIII SMP Negeri 1 Sumarorong.

Populasi adalah seluruh subyek penelitian. Jadi Populasi dalam penelitian ini adalah seluruh peserta didik kelas VIII sebanyak 5 kelas dengan jumlah peserta didik 116 orang. Untuk lebih jelasnya, populasi pada penelitian ini ditentukan pada tabel berikut.

Tabel 2. Daftar kelas, jenis kelamin, dan jumlah peserta didik kelas viii smp negeri

1 sumarorong tahun pelajaran 2019/2020

(Sumber : Tata Usaha SMP Negeri 1 Sumarorong)

\begin{tabular}{|c|c|c|c|c|}
\hline \multirow{2}{*}{ No } & \multirow{2}{*}{ Nama Kelas } & Laki-laki & Perempuan & \multirow{2}{*}{ Total } \\
\cline { 3 - 4 } & & & & \\
\hline 1 & Kelas VIII A & 12 orang & 12 orang & 24 orang \\
\hline 2 & Kelas VIII B & 6 orang & 12 orang & 18 orang \\
\hline 3 & Kelas VIII C & 14 orang & 13 orang & 27 orang \\
\hline
\end{tabular}


PEPATUDZU: Media Pendidikan dan Sosial Kemasyarakatan p-ISSN: 2087-3476 | e-ISSN: 2541-5700

\begin{tabular}{|c|c|c|c|c|}
\hline 4 & Kelas VIII D & 13 orang & 9 orang & 22 orang \\
\hline 5 & Kelas VIII E & 12 orang & 13 orang & 25 orang \\
\hline \multicolumn{2}{|c|}{ Jumlah } & 57 orang & 59 orang & 116 orang \\
\hline
\end{tabular}

Adapun sampel dalam penelitian ini adalah kelas VIIIA dan kelas VIIIB. Kelas VIIIA sebagai kelas eksperimen dan kelas VIIIB sebagai kelas kontrol, dengan jumlah sampel 42 orang.

Instrument penelitian adalah alat yang digunakan untuk memperoleh data yang dibutuhkan dalam penelitian yang digunakan untuk mengukur nilai variabel yang diteliti. Instrument yang digunakan dalam penelitian ini adalah tes hasil belajar peserta didik yang diberikan pada kelas kontrol dan kelas eksperimen sebelum dan setelah pelaksanaan pembelajaran.

Adapun teknik analisis data yang digunakan untuk menganalisis data yang diperoleh adalah dengan menggunakan analisis statistika deskriptif dan analisis statistika inferensial.

\section{HASIL DAN PEMBAHASAN}

Analisis Statistika Deskriptif

1. Statistik Skor Hasil Belajar Peserta Didik (Pre-test) Sebelum Menggunakan Model Pembelajaran Inkuiri.

Dari hasil analisis deskriptif sebagaimana terlampir maka statistik skor hasil belajar matematika peserta didik kelas VIII A dirangkum dalam tabel berikut.

Tabel 3. Statistik skor hasil belajar pre-test peserta didik kelas VIII A (kelas eksperimen) SMP Negeri 1 Sumarorong.

(Sumber: Data Diolah Pret-Test Kelas VIII A SMP Negeri 1 Sumarorong)

\begin{tabular}{|l|l|c|}
\hline \multicolumn{2}{|c|}{ Statistics } \\
\hline \multirow{2}{*}{$\mathbf{N}$} & Valid & 24 \\
\cline { 2 - 3 } & Missing & 0 \\
\hline Mean & 54.94 \\
\hline Median & 57.29 \\
\hline Mode & 62.50 \\
\hline Std. Deviation & 10.98 \\
\hline Sum & 1313.69 \\
\hline Minimum & 31.25 \\
\hline Maximum & 72.91 \\
\hline
\end{tabular}


PEPATUDZU: Media Pendidikan dan Sosial Kemasyarakatan p-ISSN: 2087-3476 | e-ISSN: 2541-5700

2. Statistik Skor Hasil Belajar Peserta Didik (Pre-Test) Tampa Menggunakan Model Pembelajaran Inkuiri.

Dari hasil analisis statistika deskriptif sebagaimana terlampir, maka statistik skor hasil belajar matematika peserta didik kelas VIII B dirangkum dalam table berikut :

Tabel 4. Statistika skor hasil belajar matematika (pre-test) peserta didik kelas

VIII B (kelas kontrol) smp negeri 1 sumarorong.

(Sumber: Data diolah Pret-Test Kelas VIII B SMP Negeri 1 Sumarorong)

\begin{tabular}{|l|l|c|}
\hline \multicolumn{2}{|c|}{ Statistics } \\
\hline \multirow{2}{*}{$\mathbf{N}$} & Valid & 18 \\
\cline { 2 - 3 } & Missing & 0 \\
\hline Mean & 53.80 \\
\hline Median & 56.25 \\
\hline Mode & $56.25^{\mathrm{a}}$ \\
\hline Std. Deviation & 12.74 \\
\hline Sum & 968.47 \\
\hline Minimum & 31.25 \\
\hline Maximum & 79.16 \\
\hline
\end{tabular}

3. Statistik Skor Hasil Belajar Peserta Didik (Pos-test) Setelah Diajar Dengan Menggunakan Model Pembelajaran Inkuiri.

Dari hasil analisis statistika deskriptif sebagaimana terlampir, maka statistik skor hasil belajar matematika peserta didik untuk kelompok eksperimen dirangkum dalam tabel berikut:

Tabel 5. Statistika skor hasil belajar (post-test) peserta didik kelas VIII A (kelas eksperimen) SMP Negeri 1 Sumarorong.

(Sumber: Data diolah Post-Test Kelas VIII A SMP Negeri 1 Sumarorong)

\begin{tabular}{|l|l|c|}
\hline \multicolumn{2}{|c|}{ Statistics } \\
\hline \multirow{2}{*}{$\mathrm{N}$} & Valid & 24 \\
\cline { 2 - 3 } & Missing & 0 \\
\hline Mean & 78.17 \\
\hline Median & 78.20 \\
\hline Mode & 87.17 \\
\hline Std. Deviation & 13.09 \\
\hline Sum & 1876.10 \\
\hline Minimum & 51.28 \\
\hline Maximum & 100.00 \\
\hline
\end{tabular}


4. Statistik Skor Hasil Belajar Peserta Didik (Pos-Test) Yang Diajar Tampa Menggunakan Model Pembelajaran Inkuiri. (Kelas Kontrol)

Dari hasil analisis statistika deskriptif sebagaimana terlampir, maka statistik skor hasil belajar matematika peserta didik untuk kelas kontrol dirangkum dalam tabel berikut

Tabel 6. Statistika skor hasil belajar matematika (postest) peserta didik kelas VIII B (Kelas Kontrol) SMP Negeri 1 Sumarorong.

(Sumber: Data diolah Post-Test Kelas VIII B SMP Negeri 1 Sumarorong)

\begin{tabular}{|l|l|c|}
\hline \multicolumn{2}{|c|}{ Statistics } \\
\hline \multirow{2}{*}{$\mathrm{N}$} & Valid & 18 \\
\cline { 2 - 3 } & Missing & 0 \\
\hline Mean & 68.81 \\
\hline Median & 71.79 \\
\hline Mode & $51.28^{\mathrm{a}}$ \\
\hline Std. Deviation & 12.47 \\
\hline Sum & 1238.60 \\
\hline Minimum & 43.58 \\
\hline Maximum & 87.17 \\
\hline
\end{tabular}

\section{Analisis Statistika Inferensial}

Pengujian normalitas data dilakukan terhadap data hasil belajar pada kelas kontrol dan kelas eksperimen. Uji tersebut dilakukan dengan uji Kolmogorov-Smirnova menggunakan program SPSS 21 for Windows dengan taraf signifikansi 0,05 .

Tabel 7. Tes nomalitas hasil pretest kelas eksperimen

(Sumber: Data diolah Pres-Test Kelas VIII A SMP Negeri Sumarorong)

\section{Tests of Normality}

\begin{tabular}{|l|c|c|c|c|c|c|}
\hline \multirow{2}{*}{} & \multicolumn{3}{|c|}{ Kolmogorov-Smirnov ${ }^{\mathrm{a}}$} & \multicolumn{3}{c|}{ Shapiro-Wilk } \\
\cline { 2 - 7 } & Statistic & Df & Sig. & Statistic & Df & Sig. \\
\hline $\begin{array}{l}\text { Preetest } \\
\text { Eksperimen }\end{array}$ & .131 & 24 & $.200^{*}$ & .966 & 24 & .578 \\
\hline
\end{tabular}

Tabel 8. Tes Nomalitas Pretest Kelas Kontrol

(Sumber: Data diolah free-Test Kelas VIII B SMP Negeri 1 Sumarorong)

\begin{tabular}{|l|c|c|c|c|c|c|}
\hline \multirow{2}{*}{} & \multicolumn{3}{|c|}{ Kolmogorov-Smirnov ${ }^{\mathrm{a}}$} & \multicolumn{3}{c|}{ Shapiro-Wilk } \\
\cline { 2 - 7 } & Statistic & Df & Sig. & Statistic & Df & Sig. \\
\hline $\begin{array}{l}\text { Pretest } \\
\text { Kontrol }\end{array}$ & .132 & 18 & $.200^{*}$ & .977 & 18 & .912 \\
\hline
\end{tabular}


PEPATUDZU: Media Pendidikan dan Sosial Kemasyarakatan p-ISSN: 2087-3476 | e-ISSN: 2541-5700

Berdasarkan tabel 7 dan tabel 8, maka dapat disimpulkan bahwa data pretest pada kelas kontrol dan kelas eksperimen berdistribusi normal.

Tabel 9. Tes Nomalitas Postest Kelas Eksperimen (Sumber: Data diolah Post-Test Kelas VIII A SMP Negeri 1 Sumarorong)

Tests of Normality

\begin{tabular}{|l|c|c|c|c|c|c|}
\hline \multirow{2}{*}{} & \multicolumn{3}{|c|}{ Kolmogorov-Smirnov ${ }^{\mathrm{a}}$} & \multicolumn{3}{c|}{ Shapiro-Wilk } \\
\cline { 2 - 7 } & Statistic & Df & Sig. & Statistic & Df & Sig. \\
\hline $\begin{array}{l}\text { Postest } \\
\text { Eksperimen }\end{array}$ & .135 & 24 & $.200^{*}$ & .943 & 24 & .195 \\
\hline
\end{tabular}

Tabel 10. Tes Nomalitas Postest Kelas Kontrol

(Sumber: Data diolah Post-Test Kelas VIII B SMP Negeri 1 Sumarorong)

Tests of Normality

\begin{tabular}{|l|c|c|c|c|c|c|}
\hline \multirow{2}{*}{} & \multicolumn{3}{|c|}{ Kolmogorov-Smirnova } & \multicolumn{3}{c|}{ Shapiro-Wilk } \\
\cline { 2 - 7 } & Statistic & Df & Sig. & Statistic & Df & Sig. \\
\hline $\begin{array}{l}\text { Postest } \\
\text { Kontrol }\end{array}$ & .180 & 18 & .127 & .941 & 18 & .306 \\
\hline
\end{tabular}

Berdasarkan tabel 9 dan tabel 10, maka dapat disimpulkan bahwa data postest pada kelas kontrol dan kelas eksperimen berdistribusi normal.

Uji homogenitas dilakukan untuk mengetahui apakah kelompokkelompok sampel yang diambil berasal dari populasi dengan variansi yang sama atau homogen.

Tabel 11. Hasil Uji homogenitas

(Sumber: Data diolah Post-Test SMP Negeri 1 Sumarorong)

Test of Homogeneity of Variance

\begin{tabular}{|c|c|c|c|c|c|}
\hline & & $\begin{array}{c}\text { Levene } \\
\text { Statistic }\end{array}$ & dfl & df 2 & Sig. \\
\hline \multirow{4}{*}{ Data } & Based on Mean & .007 & 1 & 40 & .935 \\
\hline & Based on Median & .059 & 1 & 40 & .810 \\
\hline & $\begin{array}{l}\text { Based on Median and } \\
\text { with adjusted df }\end{array}$ & .059 & 1 & 39.948 & .810 \\
\hline & Based on trimmed mean & .018 & 1 & 40 & .894 \\
\hline
\end{tabular}


Hipotesis yang akan yang diuji dengan menggunkan statistik uji-t adalah penerapan model pembelajaran inkuri lebih efektif meningkatkan hasil belajar matematika peserta didik kelas VIII SMP Negeri 1 Sumarorong jika dibandingkan dengan pembelajaran tampa menggunakan model pembelajaran Inkuiri.

Berdasarkan hasil analisis data, kedua kelompok berdistribusi normal dan homogen, sehingga pengujian hipotesis dilakukan dengan menggunakan statistik uji-t. Berdasarkan statistik uji-t dengan SPSS 21 For Windows diperoleh nilai signifikan $0,024<0,05 \mathrm{Hal}$ ini menunjukkan bahwa $\mathrm{H}_{0}$ ditolak dan $\mathrm{H}_{1}$ diterima. Dengan demikian dapat disimpulkan bahwa model pembelajaran inkuiri berpengaruh terhadap hasil belajar matematika pada peserta didik Kelas VIII SMP Negeri 1 Sumarorong. Hal ini sejalan dengan hasil penelitin yang dilakukan yang menemukan bahwa penerapan model inkuiri terbimbing dengan media grafis berpengaruh terhadap hasil belajar siswa (Putra dkk, 2014). Selain itu, berdasarkan hasil penelitian yang dilakukan Arlianty (2015) menyatakan bahwa penggunaan model pembelajaran inkuiri terbimbing berbasis konstruktivis cocok digunakan sebagai referensi pemilihan model pembelajaran.

\section{SIMPULAN}

Berdasarkan hasil penelitian dan pembahasan yang telah diuraikan sebelumnya, maka dapat disimpulkan bahwa model pembelajaran inkuiri berpengaruh terhadap hasil belajar matematika pada peserta didik kelas VIII SMP Negeri 1 Sumarorong. Dilihat dari hasil belajar peserta didik yaitu pada nilai rata-rata pretest peserta didik kelas eksperimen 54,94 dan postest meningkat menjadi 78,17.sedangkan kelas kontrol nilai rata-rata pretest 53,80, dan nilai ratarata postest 68,81. Serta uji-t dengan SPSS 21 For Windows diperoleh nilai signifikan $0,024<0,05$. Hal ini menunjukkan bahwa $\mathrm{H}_{0}$ ditolak dan $\mathrm{H}_{1}$ diterima. Dengan demikian dapat disimpulkan bahwa model pembelajaran inkuiri berpengaruh terhadap hasil belajar matematika pada peserta didik Kelas VIII SMP Negeri 1 Sumarorong.

\section{SARAN}

Berdasarkan hasil dan temuan yang diperoleh dalam penelitian ini, dikemukakan beberapa saran sebagai berikut. Bagi peneliti selanjutnya, yang akan mengkaji rumusan yang serupa diharapkan dapat mengembangkan rancangan penelitian lebih baik lagi dengan mengkaji model pembelajaran inkuiri secara mendalam lagi. Bagi guru dalam menjalankan tugas sebagai pemegang kendali dalam pembelajaran hendaknya dapat menjadikan model pembelajaran inkuiri sebagai salah satu model alternatif dalam pembelajaran untuk mata pelajaran matematika untuk meningkatkan hasil belajar peserta didik. 
PEPATUDZU: Media Pendidikan dan Sosial Kemasyarakatan p-ISSN: 2087-3476 | e-ISSN: 2541-5700

\section{DAFTAR PUSTAKA}

Arlianty, W. N. (2015). Pemanfaatan Penggunaan Model Pembelajaran Inkuiri Terbimbing Berbasis Konstruktivis Pada Materi Hidrolisis Garam Semester Genap SMA Negeri 1 Kartasura Tahun Ajaran 2013/2014. JURNAL PENDIDIKAN SAINS (JPS), 3(2), 72-77.

Karenta, R. K. R., Rasmiwetti, R., \& Rery, R. U. R. U. (2013). Penerapan Model Pembelajaran Inkuiri Terbimbing (Guided Inquiry) Untuk Meningkatkan Prestasi Belajar Siswa Pada Pokok Bahasan Hidrolisis Garam Di Kelas XI IPA SMA Negeri 5 Pekanbaru. Jurnal Online Mahasiswa Fakultas Keguruan dan Ilmu Pendidikan Universitas Riau, 2(1), 1-9.

Nur, A., Kundera, I. N., \& Tangge, L. N. (2016). Pengaruh model pembelajaran inkuiri dan gaya kognitif terhadap hasil belajar siswa pada mata pelajaran Biologi di kelas XI IPA MAN 2 Model Palu. Mitra Sains, 6(3), 258-267.

Rini, E. S. (2016). Pemahaman Konsep Dan Motivasi Belajar Matematika Siswa Kelas X Madrasah Aliyah Negeri 1 Palu Melalui Model Pembelajaran Berbasis Masalah Dan Model Pembelajaran Inkuiri. e-jurnal Mitra Sains. EJurnal Mitra Sains, 4(2), 20-29.

Purwanto, A. (2012). Kemampuan berpikir logis siswa SMA Negeri 8 kota Bengkulu dengan menerapkan model inkuiri terbimbing dalam pembelajaran fisika. EXACTA, 10(2), 133-135.

Putra, E. P., Garminah, N. N., Hum, M., \& Japa, I. G. N. (2014). Pengaruh Model Pembelajaran Inkuiri Terbimbing Berbantuan Media Grafis Terhadap Hasil Belajar Matematika Kelas IV SD di Gugus 4 Kecamatan Busungbiu. MIMBAR PGSD Undiksha, 2(1).

Sanjaya, Wina. 2010. Strategi Pembelajaran Berorientasi Standar Proses Pendidikan. Jakarta: Kencana. 